\title{
Transnational academic mobility in universities: the impact on a departmental and an interpersonal level
}

\author{
Marit Greek $^{1} \cdot$ Kari Mari Jonsmoen ${ }^{1}$ \\ Published online: 3 June 2020 \\ (C) The Author(s) 2020
}

\begin{abstract}
This article deals with internationalization in the field of higher education, focusing on the impact of transnational academic mobility on the university communities. Drawing on the results of a qualitative research study at different departments in a Norwegian university, this article explores the interaction between transnational academics and their Norwegian counterparts in an academic professional community. The key questions are the impact of internationalization on the working day at the departmental level, and how academics themselves experience working together with colleagues from all over the world. The topics are presented in the following four themes: informal interaction, cooperation, language practices, and internationalization. In the light of data gained through observation and informal dialogs in two departments that collectively consisted of 108 academic staff members, and formal interviews with 34 of them, both transnational and national, the paper concludes that the academics regard internationalization as a great source of professional knowledge. However, considerable institutional and personal adjustment is required to fully exploit the professional potential of diversity among the academic staff.
\end{abstract}

Keywords Higher education · Transnational academic mobility · Language practices ·

Socialization $\cdot$ Academic workplace $\cdot$ Communication

\section{Introduction}

Internationally recruited academics are regarded as an enrichment to European universities, and as essential to shoring up prestige and academic output in the receiving institutions (Bolton \& Kuteeva 2012; Kreber \& Hounsell 2014; Uusimaki \& Garvis 2017; Walker 2015). Consequently, European countries, including Norway, have committed to encouraging and enhancing cross-border activity in universities by attracting academics to European universities

Kari Mari Jonsmoen

karim@oslomet.no

1 Oslo Metropolitan University, Postboks 4, St. Olavs Plass, 0130 Oslo, Norway 
(OECD 2004; EHEA 2012; EHEA 2015). The Norwegian Ministry of Education and Research underscores the need of international knowledge and experience, and of the importance of employing academics from outside Norway (Ministry of Education and Research 2014). The number of internationally recruited academics has increased in Norwegian universities (NIFU 2017; NIFU 2019). However, the fast-growing number of academics who are born, educated, and encultured outside Norway and who do not have a Scandinavian language as their mother tongue represents a new situation in many Norwegian universities. This new situation is challenging, especially in universities educating students mainly for services to be provided to Norwegian society, such as education, health, and social work, where proficiency in Norwegian or another Scandinavian language is decisive.

Although English is the common language of research and scholarly publication, Norwegian is the main language in Norwegian universities. Consequently, being able to communicate in Norwegian is an advantage for academics working in Norwegian higher education. Employee participation and cooperation are core elements institutionalized in the Nordic notion of a democratic working life, representing both an obligation and a fundamental right in Norway, incorporated in the Working Environment Act (Ministry of Labour and Social Affairs 2019). Employees are expected to participate in academic, pedagogical, and organizational discussions in the workplace, as well as give consultative comments to the ministry concerning research and teaching. Consultations from the Ministry and from the University administration are conducted mainly in Norwegian, and participation, therefore, requires proficiency in the Norwegian language. Although there has been a noticeable increase in the teaching of university courses through the medium of English in Norway (Schwach \& Elken 2018), Norwegian is still the main teaching language and many Norwegian academics (NAs) prefer to use the national language in academic discourses and in informal interactions with colleagues during the working day. Findings from studies at Swedish universities reveal a similar pattern and conclude that although English is crucial to meeting the demands of internationalization, proficiency in the Swedish language is important as a means of communication, for being included as an equal member of the faculty, and for gaining authority and participating actively in decision-making processes (Andersson 2014; Behtoui \& Leivestad 2019; Mählck \& Thaver 2010).

Despite extensive transnational academic mobility, few studies have been conducted on transnational academic mobility as a topic, and even fewer on the impact it has on the universities concerning the role of language in an increasingly diverse academic community. Existing research focuses mainly on challenges experienced by transnational academics (TNAs) in an English-speaking context without having English as their mother tongue (Behtoui \& Leivestad 2019; Green 2009; Hsieh 2012; Luxon \& Peelo 2009; Morley et al. 2018; Pherali 2012; Uusimaki \& Garvis 2017; Walker 2015). The common acknowledgment is that language and language practices in multilingual workplaces are crucial to socialization and integration in the working community. Research concludes that internationally recruited academics tend to feel isolated, and that one of the main causes is language barriers (Andersson 2014; Kreber \& Hounsell 2014; Maximova-Menzoni \& Egeland 2019; Negretti \& Garcia-Yeste 2015). Green (2009) and Mählck and Thaver (2010) focus on the need to master both written and oral communication with fellow colleagues. However, research on transnational academics mainly focusses on lack of cultural knowledge as a threat to academic status and identity, as well as a challenge in dealing with academic activities (Pherali 2012; Walker 2015). Studies have also been conducted on the career trajectories of academics within Europe (Ackers 2005; Ackers \& Gill 2005; Morano-Foadi 2005; Musselin 2004), including 
long-term geohistorical perspectives (Taylor et al. 2008) and how factors such as gender and migrant background affect opportunities for successful careers (Behtoui \& Leivestad 2019; Mählck 2016). In Scandinavia, little attention has been paid to the benefits or challenges of employing academics from abroad or to the impact on universities as an academic workplace. According to the Norwegian Work Research Institute, the impact of diversity among employees in academia is an understudied field, both in Norway and in the rest of Scandinavia, and research on the topic is fragmentary and grounded on weak empirical evidence (Maximova-Menzoni et al. 2016). The focus has mainly been on the political level in terms of language planning in the wake of increasing use of English in Norwegian universities, parallel language use, and the risk of Norwegian becoming a minority language in Norwegian academia (Kristiansen 2012; Kristoffersen et al. 2014).

Our research study responds to the paucity of studies exploring the impact of transnational mobility in academic communities in Norwegian as well as in other Scandinavian universities. The study was carried out at a teaching-oriented university providing education aiming to prepare students for working life and societal challenges in Norwegian society. Because the study is context-bound and was conducted on a limited sample of academics in a Norwegian university, the findings are not generalizable. However, they are transferable to other teachingoriented universities, where proficiency in the national language is considered to be of great importance. The study gives a picture of a specific context, raising critical questions and offering a reasoned judgment about the impact of transnational academic mobility on a departmental and an interpersonal level. This article aims to form a picture of language practices in academic communities, focusing on interaction and cooperation between fellow academics.

\section{The study: approach and methodology}

Our article is based on a qualitative study conducted in 2018-2019. Data was collected from two departments offering programs in civil engineering, energy technology, and computer science. The aim has been to seek knowledge beyond statistics and policy directions regarding interaction and academic collaboration between colleagues, uncovering the impact of transnational academic mobility experienced by the academics in everyday working life. In both departments, academics have traditionally been recruited largely from Norway, and Norwegian has been the common language. However, this situation is rapidly changing. Today, 41 percent of academics in the departments studied are internationally recruited and have a first language other than Norwegian or another Scandinavian language. The departments, therefore, represent an interesting field for research which can shed light upon experienced benefits and challenges of extensive transnational academic mobility in higher education.

Our empirical foundation consists of data collected from participant observation, spontaneous conversations, and semi-structured interviews. The study aims to add new knowledge about the impact of increased academic mobility on how academics interact and collaborate. Neither the academics' country of origin nor their academic position as professors, associate professors, assistant professors, head engineers, or $\mathrm{PhD}$ candidates are significant to the findings in our study. They are all academic employees at the university and have both teaching and research obligations. Although academic position makes a difference to the proportion of teaching obligations and afforded individual research, academic employees at the university generally have similar responsibilities. Observations, informal dialogs, and 
formal interviews revealed no notable differences among TNAs in different academic positions, concerning perspectives and stances regarding teaching, supervision, and social integration. In this article, TNAs are therefore not differentiated, but considered as one category. Our sample consists of observation in two departments that collectively included 108 academics, and formal interviews with 34 of them, comprising both NAs with most of, or all their educational experience from Norwegian educational institutions, and TNAs who are born, educated, and encultured outside Scandinavia.

Data was collected over a one-semester period. Aiming to achieve validity and reliability, we used different modes of data collection, alternating between observing, participating, and interviewing, as suggested by Fangen (2010) and Stewart (1998). Field notes were made continuously, both observation notes and notes on theoretical questions and assumptions. We jointly discussed our field notes and made preliminary analyses which resulted in new perspectives and questions.

As members of the university's academic staff but not of the faculty studied, we were both colleagues and visitors, insiders and outsiders. According to Smyth and Holian (2008), being an insider is advantageous in terms of being able to understand the issues raised by the informants, and of being capable of grasping the realities of everyday life for the academics in the university. As insiders, our advantage has been knowing the institution and the formal and informal power structures. As insiders, however, we are at risk of being influenced by our similarity with our informants because our prior knowledge constitutes a bias which may lead us to analyze the data collected less critical than outsiders. As underscored by Smyth and Holian (2008), reliability requires an awareness of the possible effects of perceived bias on data collection and analysis. Mercer brings up the challenge of objectivity and prejudice, and emphasizes that insiders "often enjoy freer access, stronger rapport, and a deeper, more readily available frame of shared reference with which to interpret the data they collect", but at the same time emphasizes the need to "contend with their own pre-conceptions" (Mercer 2007 p.13). In order to approximate objectivity, ensure veracity, and alleviate our influence on informants' views, we avoided making active contributions or initiating any discussions concerning the topics raised by the informants in spontaneous conversations and formal interviews. We only asked follow-up or clarifying questions when necessary.

The academics gradually became accustomed to us observing them throughout the semester, walking the corridors, participating in meetings, and talking to people. This gave us the best possible opportunity to collect naturally occurring data under everyday conditions, making it possible for the staff to freely share their reflections and opinions with us whenever they wished to. The spontaneous expressions that occur in such informal settings are less forthcoming in the more formal interviews, and therefore represent essential data that would otherwise not emerge. Mercer (2007) brings up the ethical dilemma concerning the risk of using "incidental" data, that is, data to which an insider has access, but which is not meant to be used in a research study. As researchers, we are highly conscious of this challenge.

In addition to the informal dialogs with different employees during the workdays, successive formal interviews, each lasting 20-45 minutes, were carried out throughout the semester. The interviews were conducted in Norwegian or English, depending on the informants' choice of language. All the academics at the two departments were invited to participate through staff meetings and an information letter. Due to lack of response, we directly took contact with all the academics who were present in their offices on a random working day and asked for interviews. Thirty-four informants participated in the formal interviews, representing the different academic positions in the departments. Nineteen of the informants were TNAs and 
15 were NAs. In order to ensure anonymity, the gender distribution among our participants is not specified. All the interviews were digitally recorded, anonymized, and subsequently transcribed verbatim. The interviews were semi-structured, with open-ended questions, organized around four main issues: (1) an ordinary working day, (2) the meaning and consequences of internationalization, (3) language practices, and (4) integration and cooperation.

When analyzing data, we used a bricolage approach as described by Brinkmann and Kvale (2015). The first step was to perform a thematic analysis. Transcripts and field notes were read closely and repeatedly, analyzing the content and identifying the main tendencies, noting patterns and grouping utterances and observations into representative themes. We searched plausibility and a coherent assembly of data, ensuring that validation permeated all stages of the analytical process. Our analysis did not find any gender-based differences in the statements given by the informants. This was true for the informal dialogs as well as for the formal interviews. We compared data for similarities and differences, discussing and agreeing on themes which captured as accurately as possible the fullness of the experiences described by the informants and our own observations. We then deducted the different themes raised by the informants according to our interpretation of the data and to the recurrent emergence of the themes, and further synthesized them into four categories: (1) informal interaction, (2) cooperation, (3) language practices, and (4) internationalization. The categories reflect how the impact of academic mobility is interconnected within the department, embodied in and influencing local practices. Language skills are a recurrent topic when the informants discuss how they experience transnational academic mobility in their everyday working life. In fact, language skills appear as an important component in all four categories.

Customary ethical standards have been followed. The research project was approved by the Norwegian Centre for Research Data. The head of the two departments was informed, formal meetings with the academics were held to inform them of the nature of the study, and consent to carry out the fieldwork and interview members of the academic staff was obtained.

\section{Findings}

\section{Informal interaction}

Generally, the academics consider informal interaction with colleagues as important and necessary for social integration. However, their definitions of integration differ. One informant defines integration in the working community as sharing personal and professional matters with each other. Another informant defines integration as being listened to in academic discussions, and not being left behind when colleagues go for lunch. A third informant claims that integration presupposes that the working environment invests in TNAs and emphasizes cooperation with colleagues. In this informant's opinion, social integration also demands learning Norwegian. According to his experience "You feel a lot more included when you talk to your colleagues in Norwegian." The informant adds: "You have to become firmly rooted, otherwise Norway will only be a stopover before the next destination."

Several informants report that they do not really know their colleagues. Both NAs and TNAs report that the way the curriculum is organized makes it difficult to meet up with their colleagues during the working day: "Earlier we had half an hour when we all were free [...]. Now we are teaching all day long, and don't see our colleagues anymore." The different work routines are also mentioned as an impediment to informal contact between colleagues, 
exemplified by NAs arriving early in the morning, having lunch early, and leaving early, and TNAs tending to start their working day later, eat later, and leave later. One would think that lunchtime is an opportune time to get to know your colleagues, chatting about everyday subjects or informally discussing academic matters. However, even though the majority tells us that socializing at lunch is important, few eat lunch with their colleagues, and if they do, the NAs group together, as do the TNAs. One NA says: "It is my impression that they [the TNAs] gather with others from abroad and eat at a different place." According to the TNAs themselves, they simply prefer eating a hot lunch later in the day rather than the bread and cold cuts offered in the faculty's canteen at noon.

The data reveals a distinct difference of opinion concerning the importance of informal interaction between TNAs and NAs. Many NAs underscore the significance of knowing each other, and in formal interviews, they reveal a preoccupation with the challenge of understanding each other. According to one NA, the difficulty of understanding each other makes social contact problematic: "there quite simply is no contact. We don't get to know each other without talking together." Only NAs notice this issue. The majority of TNAs are satisfied. They mostly feel accepted and comfortable in their academic positions in the department, and only a few actively seek contact with their colleagues. One TNA says: "I have a lot to do, and prefer sitting in my office, concentrating." Another says: "I am very happy to be a colleague here. [...] I feel included and integrated, perhaps not in terms of speaking the language, but otherwise."

Although most of NAs underscore the need to informally interact with their colleagues, some say that they sometimes feel social interaction as forced, due to poor proficiency in English. In addition, communicating in English with a colleague who has different frames of references in everyday life makes it difficult. One NA states that it is like "a constant interview situation, questioning and answering". To TNAs, the matter of language is more a question of learning Norwegian than of speaking English fluently. In various ways, TNAs express that they should have learned more Norwegian. As one informant explains: "Almost every email here is in Norwegian, about concerts, people retiring [...]. When everyone is speaking Norwegian, it is hard to understand what is going on. I want to be able to speak Norwegian. I'd like to learn it." At the same time, they acknowledge the challenges the NAs are facing: "My Norwegian colleagues, they also need time to get used to me speaking Norwegian". Several TNAs find it difficult to socialize with their Norwegian colleagues. One says that it is "hard to get to know Norwegians," and is supported by others: "to get to know them [Norwegian colleagues], to be their friends, it's a challenge because I think I have to speak Norwegian better. [...] so, I try my best to learn Norwegian."

\section{Cooperation}

Social interaction with colleagues through academic cooperation seems more important to the informants than informal contact, as academic interests and tasks appear to connect colleagues more than small talk during breaks. Linguistic challenges, however, are not an issue when talking about cooperation between colleagues but is brought forward in connection with meeting activities. If they do not understand what is being said or are unable to express themselves as they wish, and if the meeting theme is not perceived as directly relevant to their work, some informants choose not to attend the meeting.

According to our informants, creating a sense of community through academic cooperation is essential to a well-functioning workplace. Nevertheless, both TNAs and NAs express that little cooperation between the various academics in the same department takes place in 
research activities, article writing, or teaching activities. One of the informants puts it as follows:

Cooperation only takes place through extensive research projects, for example, research with funding from the Research Council of Norway or other funding institutions, where cooperation is required. But there should be room for collaboration in teaching as well, developing syllabuses together.

The reason given for the absence of academic cooperation is that the daily schedule lacks flexibility, everybody has too much to do and does not know each other's areas of expertise and fields of interest. Despite all academics participating in research groups, based on their individual research interests, and regular lunch-meetings arranged as a way for staff to present their work and get to know each other, some informants claim that it is only by chance that they learn about their colleagues' academic interests and experience. One TNA says that he would like to know more about his colleagues' research and claims that: "I'm not aware of... if the professors are doing research." However, many informants express a feeling of inclusion and academic fellowship, saying that they know about their colleagues' academic interests and ongoing projects.

In keeping with democratic tradition, regular formal staff meetings are arranged. These represent an opportunity for all employees to collaborate with their colleagues, making decisions on issues concerning themselves and their work. However, several of our informants do not attend. This is partly because they find it difficult expressing themselves in English or do not speak Norwegian, and partly due to their workload and because formal matters discussed at these meetings do not always affect them. One of the directors of studies explains the lack of participation as follows:

People complain that we don't have fellowship. But at the same time the fellowship is not really that important to them because they have the group that they work with and they're really successful. We are the most productive department when it comes to research, and that's because people just get on with their work, and they don't waste time going to meetings.

Whatever the reason, the fact that academics do not regularly attend the faculty meetings is perceived as problematic to many informants, because joint decision-making on matters concerning study programs and institutional matters is regarded as essential. Some informants explicitly mention this challenge.

\section{Language practices}

The university's aim for internationalization and increased recruitment of TNAs obviously affects the department, influencing traditions and deeply rooted convictions about the students, engineering as a profession and the daily work at the department. Discussions concerning internationalization constitute an ongoing and repetitive phenomenon among the informants. Language is a core element in these discussions. The informants express contradictory meanings. They claim that language is no problem to them personally, yet on the other hand, they find the extensive use of English or Norwegian a challenge at departmental level.

When interacting with their colleagues, the academics alternate between Norwegian and English, depending on their respective language skills. The NAs clearly state that they appreciate their fellow colleagues from abroad and wish to be linguistically flexible. One 
NA says: "I never think about which language I use." The common opinion among both NAs and TNAs is that the main objective is to understand each other. One informant says: "We have high tolerance for each other and for the different language competencies. We all wish to contribute to a good working environment. We [the NAs] are considerate and switch to English when necessary". One TNA says:

Most days I engage in some communication with my colleagues. English or Norwegian - it depends. Around the corridor and at lunchtime it's mostly...nowadays it's mostly Norwegian. Usually the others [the NAs] will speak English to me, but I try to make it more Norwegian, so it's a mixture.

In interviews and informal dialogs, the issue of the informants' own language competence in English or Norwegian is played down, underscoring that the problem lies in the level of context-bound language proficiency, diverging interests and the conversation topic. However, language clearly matters to both TNAs and NAs in informal conversations and during breaks. When asked directly, a TNA tells us that it is preferable to speak English during lunch breaks rather than having a lunchtime conversation in a language one does not fully master. One NA, however, prefers speaking Norwegian, especially at lunchtime: "I always have lunch with my colleagues who speak Norwegian. It's OK to speak English when discussing subject matters and exchange ideas, that's no problem. But when I socialize..."

Formal meetings are conducted in a mix of Norwegian and English, showing consideration to all the participants. However, the academics have different views on this practice. While the TNAs are mainly satisfied with the dual use of language in meetings, several of the NAs feel insecure and to some extent unable to express themselves precisely when discussions take place in English. As one informant states: "If only one English speaker participates at a formal meeting in the institution, we all have to switch to English. The Norwegians then perhaps have less to say." Another informant believes that: "In reality, if everything is spoken or written in English, important information will be lost."

Other times, however, it is the other way around, and the TNAs are the ones who are unable to participate due to their lack of proficiency in Norwegian. Formal written information is generally provided in Norwegian; for example, consultation papers from the rector are written in Norwegian and require a response in Norwegian. TNAs who do not master Norwegian risk missing important work-related information, as well as the possibility to participate actively in decision-making processes. According to one of our informants, when some of the employees are deprived, the possibility to engage, "it puts democracy at risk." If an academic does not master Norwegian, active participation in matters concerning university policy is practically impossible. One TNA says:

There are several consultations every week, written in bureaucratic Norwegian. The sentences are very complicated. This means that all employees must master high-level Norwegian to be 100 percent integrated in the democratic processes in the department.

The challenge of grasping written information is dealt with in different ways. While some TNAs struggle to translate consultation papers and emails, others solve the problem like this informant: "I read the first lines and decide whether to use time on it or not. If it is important enough, I trust my leader translates it into English."

Several of the academics, both TNAs and NAs, are preoccupied with maintaining Norwegian as the dominant language within the university. However, the informants 
underscore the difference between language used in research and language used in teaching activities:

In research it is essential to seek international knowledge, both in literature and among fellow researchers. Science is the main issue, and language is trivial if one understands each other orally or written. In education and teaching, it is different. The choice of language, Norwegian or English, is crucial both to the students and to the engineering industry.

An opinion broadly shared in both departments is that all academics must master Norwegian, as expressed by the following quotes:

- "Communication within the department is no problem, but the department's communication with the workplaces is a problem."

- "English works in academia, but not in the workplaces."

- "Without a functional Norwegian disciplinary language, the candidates will not succeed in civil engineering. It is a conservative line of business [...] you must speak Norwegian. [...] English is not always enough."

- "The construction business is very Norwegian. [...] Building good relations with the construction businesses where our students will have their future workplaces is a challenge with academics not mastering Norwegian."

- "I had a meeting with a company yesterday, and I could see that speaking English was difficult for them."

However, ideas concerning the necessity to master Norwegian in the Norwegian labor market differ:

I have not experienced any problem during the years I have been here. Half of the students attending one of the master programs we offer are from abroad. Most of them walk straight out to the Norwegian labor market, and they tell that language is never an issue. Mastering English is more than enough.

Most of our informants agree that undergraduate students in general should be taught in Norwegian, except for the international classes. Consequently, it is considered as important to master Norwegian when teaching at bachelor level. One informant underscores the importance of language: "It is crucial that we maintain a high level of Norwegian language competence, especially at bachelor level." Nevertheless, as a result of the large number of TNAs who do not master Norwegian, most of the TNAs continue giving lectures and supervising in English, although they wish to be able to use Norwegian as a means of teaching and supervising in the future. One TNA tells us:

I always teach in English, both at bachelor and at master level. I don't use Norwegian because I'm afraid I won't be able to explain in an understandable way to the students. It is difficult finding the technical concepts in Norwegian. My accent is probably also distracting.

One NA comments on the consequences of the increased use of English as follows:

[I]t has an impact on bachelor programs. What happens when 25 percent of the lecturers don't master Norwegian? They teach in English. And what about the bachelor's theses? 
Although some students write their theses in English, most write them in Norwegian.

When their supervisors don't master Norwegian ... well that's a problem.

The heads of both departments recognize the linguistic challenges and offer language support to all academics. TNAs are given time on their schedule to learn Norwegian, and NAs are encouraged to further develop their English skills. The Norwegians participating in English courses is not an issue raised by the informants. Norwegian courses for TNAs, however, are of great importance to the majority. Several of our informants participate in Norwegian courses offered by the university, but because of their workload, they do not always find the time to participate and follow-up as they wish. One of our informants tells that although he has participated in a Norwegian course and has lived in Norway for many years, he barely speaks any Norwegian at work. This informant claims that: "You don't learn Norwegian by participating in a course, and because I don't speak Norwegian at home I haven't learned very much." Another informant says that he is eager to learn Norwegian and participates actively in the Norwegian course, but that progression is slow due to lack of time to practice the Norwegian language.

Some TNAs consciously use Norwegian at work as often as possible, switching to English when it is particularly important to be understood. One TNA says: "When it comes to very professional things, it is only English because I communicate better and don't risk that I don't understand something. So, I prefer to do it in English for now. This will change, but I need some time." The same seems to be the case for some of the academics with Norwegian as their first language. Although they acknowledge English as a research language and the necessity to publish in English, they feel unable to express themselves as precisely and as nuanced as they would wish at meetings conducted in English.

\section{Internationalization}

Generally, our informants understand internationalization in a broad sense of the word. They consider internationalization and internationally recruited academics as a necessity in academia. The rationale is that since academic knowledge is international, universities, where this knowledge is developed and distributed, are international. When the informants give examples of what internationalization means to them, they say it is about international experiences, about people from different nations working together, and about being open-minded about people with different backgrounds. As one informant puts it:

I think it means to be open-what happens in the world in general, professionally, especially for this kind of work and things like that. And to be willing to hire international people in jobs around here. I think the department, the university in general, is quite international.

Internationalization is also about a multilinguistic environment, e.g., a university offering study programs following international standards, using English as a means of communication, and of parallel language use. Some mention cooperation with international companies, attending international conferences, and student and staff exchanges as part of internationalization. All informants bring up collaboration with other universities in different research projects as a part of internationalization, and professional networks outside Norway seem important to the majority. One informant says: "It is impossible to be international without a network, and it helps a lot having international researchers here. [...]. We learn a lot. New 
ideas, updated knowledge." However, none of the informants emphasizes differences in international experiences or background when explaining their interpretation of an international working environment.

Notwithstanding their positive attitudes towards engaging in internationalization, what preoccupies NAs in the two departments in this study is that the number of TNAs is rapidly increasing. According to our informants, there is a need for thorough consideration of the university's recruitment strategy and how it affects the different departments. Several informants raise this issue when talking about the changes that have taken place in their departments. From one informant's point of view, it just "happens without an awareness of what we want and where we are going." Another informant says: "Employing academics from abroad cannot be the only goal. That is a nearsighted interpretation of what internationalization is." However, recruiting academics internationally is clearly regarded as an essential part of being an international university. One informant says: "You cannot employ Norwegians only, working exclusively towards the Norwegian labor market, and simultaneously talk about internationalization. Then it is just symbolical." Another informant explains: "Internationalization is necessary and beneficial to the university, we have to cooperate, and we have to share knowledge. But we must clarify the limits, how internalization is to be implemented."

Our data indicates a contradiction between the university's needs for expertise for its rating and for attracting competent scientists on the one hand, and the competence needed at the departmental level to provide high-quality study programs for the Norwegian labor market on the other. Our informants, especially the NAs, are concerned about the consequences of the university's recruitment policy and emphasize the need for academics who know the field of practice. Generally, our informants wish to recruit academics with knowledge about engineering as a profession in Norway, and about the laws and regulations. They perceive the needs of the department to conflict with the university's attempts to shore up prestige and academic output by employing academics with international knowledge and experience. Our informants say that in job announcements, the university's only concern is the applicants' academic achievements. In conjunction with the increasing number of TNAs, several NAs are worried that the pragmatic, vocational focus of study programs will gradually shift to a more academic focus. According to the NAs, newly recruited academics, especially TNAs and also some NAs, seem to have a more theoretical background and less experience in the field of practice. This development may lead to a university with academics who are more interested in research than in teaching and supervising students towards today's labor market. One informant says:

When the university recruits professors from abroad, it affects our bachelor students.

Surely, the transnational professors are excellent researchers and an asset to our students at master and $\mathrm{PhD}$ level, but what about students at bachelor level?

When discussing internationalization in terms of internationally recruited academics, language is obviously a crucial issue. The increasing number of academics who do not master Norwegian leads to an unequal distribution of tasks and to frustration among the academic staff. One informant says: "The activities that require Norwegian skills fall to those who master the language. It can be teaching, supervision, task formulations, writing a consultation paper, working in a committee, etc." According to some NAs, the students consult the Norwegianspeaking academics when they find that supervisors neither speak Norwegian nor understand 
their Norwegian written work. The informants do not blame the TNAs, but the heavy workload is frustrating and feels unfair:

It is great that the university employs the best qualified academics, independent of language, but at the same time it is problematic and frustrating that most of the administrative tasks fall to us. For instance, all the committee work, written assignments and oral examinations in Norwegian, and translating from English to Norwegian. It cannot be right.

Several NAs find that professors from abroad are mainly preoccupied with research and are only responsible for lectures from master to doctorate level, and that responsibility for undergraduate students largely is left to the Norwegian-speaking members of the academic staff. Because teaching at master level is regarded as more prestigious and is presumed to give better career prospects than teaching at bachelor level, the allocation of tasks seems unjust. Some even wonder whether the reason for not learning Norwegian is to avoid teaching undergraduate students:

If teaching exclusively at master's and doctorate level is an incentive for not learning Norwegian, it is a problem. It is unfortunate for their colleagues, but also for themselves. Personally, I think it is only fair that everybody should learn and master Norwegian, and that everybody can be responsible for the students in the low-level courses.

Lack of Norwegian language knowledge leads to an uneven division of tasks which is of great concern to the academics. "If we continue with internationalization in this way," reflects one of the informants, "we will end up with a sharp distinction between two teams: Norwegians teaching at a low level and internationals teaching at a higher level."

\section{Concluding comments}

In the two departments studied, transnational academic mobility is regarded as both natural and necessary to knowledge development and academic quality. However, the rapidly increasing diversity is experienced as challenging. In line with Otten (2009), our research study reveals that enrichment in the working environment cannot be measured solely by the number of TNAs. As in earlier research conducted in Scandinavia (Selmer et al. 2013), our findings indicate a need to focus on academics' involvement within the academic community, suggesting functional language practices to be an essential variable to beneficial internationalization of Norwegian academic communities. There are, however, crucial issues regarding language, namely whether the working language ought to be English or Norwegian, and when and in which situations one of them is preferable. Opinions on the language issue diverge among academics. Data from our informants indicates that the difference depends more on personal and academic interests - whether one is mainly research-oriented or student-oriented, age, length of stay, family situation, etc. - than on language. The majority of TNAs and several of the younger NAs seem to be highly research oriented. Others, mainly those affiliated with bachelor programs, are above all concerned about educating well-qualified engineers for the Norwegian labor market. The latter group therefore fears a weakening of the university's applied focus and a devaluation of teaching over research. Several NAs perceive the increased use of English as a means of teaching as a symbol of such a trend.

At first sight, the question of language seems to be unproblematic to our informants. The NAs find switching between English and Norwegian during the workday as relatively 
uncomplicated, and the TNAs are satisfied with the situation as it is. Nevertheless, the interviews indicate a contradiction concerning interaction between academics with different linguistic backgrounds. On the one hand, there seems to be agreement that language is no issue, while on the other hand, challenges concerning language are repeatedly mentioned in informal conversations and formal interviews. The issue of language emerges in connection with other topics, such as social contact and cooperation among colleagues, the necessity for translation, democracy in the workplace, and equal division of work tasks, e.g., teaching, supervising, curricular planning, and strategic planning. Failure to master the Norwegian language seems to be an obstacle to performing tasks in daily life at the university, resulting in more responsibilities for the NAs. Some of our informants referred to this situation as unfair practice in the department. The issue of language is also raised in discussions about social interaction in the academic community. Social interaction in one way or another is important to most of the academics. In line with Negretti and Garcia-Yeste's study in a Swedish university, lunch is identified as an arena for social interaction and information exchange (Negretti \& Garcia-Yeste 2015). However, as findings revealed among academic migrants in a researchintensive university in Scotland (Kreber \& Hounsell 2014), some of our informants find language to be a barrier in engaging in informal conversation.

The organization of physical space and working conditions also seem to be crucial to opportunities for interaction and cooperation between academics in both departments. One must also have in mind that academics make up a diverse group, and even among those sharing the same experiences and linguistic background, opinions may vary significantly. While some of the academics are newly appointed, others have held academic positions at the university for many years. Some of the academics have experience from practical work as engineers, while others have work experience from universities outside Norway. Differences in personalities must also be taken into consideration. Openness to new experiences, an ability and interest in establishing new social contacts, expectations of new friendships, and personal confidence all have a bearing on how individual academic deals with linguistic challenges.

Although our findings cannot be directly transferred to other universities, our informants have given valuable insights into crucial elements in developing equal and productive interaction between TNAs and NAs. Mutual understanding and interaction between academics with different linguistic backgrounds require functional language practices. This can only be achieved through involvement by all parties, the departmental management as well as the academics. A lingua franca is an essential component in an international academic society. Consequently, English will undoubtedly play a role in Norwegian universities in the future as a medium of teaching, research, and communication, as will the Norwegian language. It is therefore urgent to establish a productive linguistic balance where all parties feel comfortable and included in the academic community, while simultaneously protecting and further developing Norwegian as a professional language in the field of engineering. Consequently, our research study suggests that, in addition to English, proficiency in Norwegian is important as a means of communication, of inclusion as an equal member of the faculty, of gaining authority and participating actively in decision-making as well as of teaching at all levels. Our findings are supported by research studies carried out in Sweden which highlighted the importance of maintaining and further developing the national language in the Swedish universities (Andersson 2014; Behtoui \& Leivestad 2019; Mählck \& Thaver; 2010).

As Otten (2009) points out, the simple presence of TNAs on campus is not enough to develop a well-functioning international academic community. In line with Bolton and Kuteeva (2012), our findings conclude that internationalization of Norwegian universities 
and the challenges experienced by our informants raise questions of broader sociolinguistic concern. Education reflects the nation state, its values, and priorities, and although internationalization is beneficial, our findings reveal that there are also dilemmas and disadvantages in the wake of an increased transnational academic mobility. As pointed out in previous research, internationalization represents challenges to the university in terms of language, pedagogy, and administration (Luxon \& Peelo 2009; Tange 2010). As stated by Tange (2010, p.138), internationalization brings about changes in the institution "affecting among other things pedagogical practices, curriculum development, knowledge flows and the work routines of students, administrators and academic staff."

Internationalization among academics in higher education may lead to a richer, more flexible understanding of professional issues and thus to a collective consciousness. Collective consciousness implies an awareness of different and complementary views of phenomena of common concern, as defined by Bowden and Marton: "Collective consciousness, in the context of the university, presupposes shared objects of knowledge. It embraces both what is common-we talk about insights, perspectives and ways of seeing - and that which is different and therefore complementary" (Bowden \& Marton 1998, p.203). However, transnational academic mobility and frequent academic discussions do not automatically bring about knowledge transfer and professional cooperation between academics. What is critical, according to Otten (2009), is actual participation by all academics in the community discourse. "An ideal community", says Otten (2009, p.415), "should be diverse in social composition and cohesive in its mission." Thus, interaction between colleagues through a shared language is an essential key to success.

The issues raised in this article call for further research and ought to be discussed within the general community, among faculty staff, university managements, and educational leaders at universities. There is a growing number of internationally recruited academics in Norwegian universities, academics who have studied and worked in educational cultures that differ from that in Norway. Language practices are culture- and context-sensitive, and teaching and supervising students are considered part of the disciplinary discourse. Consequently, there is a need for knowledge about how diversity among academics might affect students' knowledge development. Given that our research study was conducted in a university with a high proportion of vocational programs, comparable studies ought to be carried out in other universities and other study programs, such as in departments offering programs in disciplines such as chemistry, history, or sociology.

Funding Information Open Access funding provided by OsloMet - Oslo Metropolitan University.

Open Access This article is licensed under a Creative Commons Attribution 4.0 International License, which permits use, sharing, adaptation, distribution and reproduction in any medium or format, as long as you give appropriate credit to the original author(s) and the source, provide a link to the Creative Commons licence, and indicate if changes were made. The images or other third party material in this article are included in the article's Creative Commons licence, unless indicated otherwise in a credit line to the material. If material is not included in the article's Creative Commons licence and your intended use is not permitted by statutory regulation or exceeds the permitted use, you will need to obtain permission directly from the copyright holder. To view a copy of this licence, visit http://creativecommons.org/licenses/by/4.0/.

\section{References}

Ackers, L. (2005). Scientific migration within the EU: introduction to the special issue. Innovation: The European Journal of Social Science Research, 18(3), 275-276. 
Ackers, L., \& Gill, B. (2005). Attracting and retaining 'early career' researchers in English higher education institutions. Innovation: The European Journal of Social Science Research, 18(3), 277-299.

Andersson, M. (2014). Närvaro som märks. Rasifiering och tillhörighetsarbete i den svenska akademin. In K. Sandell (Ed.), Att bryta innanförskapet. Kritiska perspektiv på jämställdhet och mångfald $i$ akademin (pp. 196-217). Makadam förlag: Gøteborg.

Behtoui, A., \& Leivestad, H. (2019). The "stranger" among Swedish "homo academicus". The International Journal of Higher Education Research, 77(2), 213-228.

Bolton, K., \& Kuteeva, M. (2012). English as an academic language at a Swedish university: parallel language use and the 'threat' of English. Journal of Multilingual and Multicultural Development, 33(5), 429-447.

Bowden, J., \& Marton, F. (1998). The university of learning: beyond quality and competence. London: Kogan Page.

Brinkmann, S., \& Kvale, S. (2015). InterViews: learning the craft of qualitative research interviewing. Thousand Oaks: Sage.

EHEA. (2012). The European Higher Education Area in 2012: Bologna Process Implementation Report. http://www.ehea.info/media.ehea.info/file/2012_Bucharest/79/5/Bologna_Process_Implementation_ Report 607795.pdf. Accessed 03 June 2020.

EHEA. (2015). The European Higher Education Area in 2015: Bologna Process Implementation Report. https:/eacea.ec.europa.eu/national-policies/eurydice/content/european-higher-education-area-2015-bolognaprocess-implementation-report_en. Accessed 03 June 2020.

Fangen, K. (2010). Deltagende observasjon. Bergen: Fagbokforlaget.

Green, D. A. (2009). New academics' perceptions of the language of teaching and learning: identifying and overcoming linguistic barriers. International Journal for Academic Development, 14(1), 33-45.

Hsieh, H.-H. (2012). Challenges facing Chinese academic staff in a UK university in terms of language, relationships and culture. Teaching in Higher Education, 17(4), 371-383.

Kreber, C., \& Hounsell, J. (2014). Being an international academic: a phenomenological study of academic migrants adjusting to working and living in Scotland. International Perspectives on Higher Education Research, 11, 9-33.

Kristiansen, M. (2012). Hvordan ivareta et norsk fagspråk i en internasjonaliserende hverdag. Om domenetap og parallellspråklig terminologiutvikling i høyere utdanning. Fagbok Forlaget Nordand, Nordisk tidsskrift for andrespråksforskning, 2(7), 85-112.

Kristoffersen, G., Kristiansen, M., \& Røyneland, U. (2014). Landrapport Norge: internasjonalisering og parallellspråklighet ved norske universitet og høyskoler. In F. Gregersen (Ed.), Hvor parallelt: om parallellspråkighet på Nordens universitet TemaNord (pp. 197-257). Copenhagen: Nordisk Ministerråd.

Luxon, T., \& Peelo, M. (2009). Academic sojourners, teaching and internationalisation: the experience of nonUK staff in a British University. Teaching in Higher Education, 14(6), 49-659.

Mählck, P. (2016). Academics on the move? Gender, race and place in transnational academic mobility. Nordic Journal of Studies in Educational Policy. https://doi.org/10.3402/nstep.v2.29784.

Mählck, P., \& Thaver, B. (2010). Dialogue on gender and race equality. Equality, Diversity and Inclusion: An International Journal, 29(1), 23-37.

Maximova-Menzoni, T., \& Egeland, C. (2019). Nationality diversity in academia: what is the problem represented to be? Nordic Journal of Working Life Studies, 9(3). https://doi.org/10.18291/njwls.v9i3.116054. Accessed 20 Jan 2020.

Maximova-Menzoni, T., Egeland, C., Askvik T., Drange I., Støren, L.A., Røsdal, T., \& Vabø, A. (2016). Being a foreigner is no advantage. Career paths and barriers for immigrants in Norwegian academia. Work Research Institute (AFI), AFI Report 12: 2016.

Mercer, J. (2007). The challenges of insider research in educational institutions: wielding a double-edged sword and resolving delicate dilemmas. Oxford Review of Education, 33(1), 1-17.

Ministry of Education and Research (2014). Knowledge cooperation. https://www.regjeringen. no/en/topics/education/innsikt/internasjonalt-kunnskapssamarbeid/internasjonaltkunnskapssamarbeid/id2356816/. Accessed 4 May 2019.

Ministry of Labour and Social Affairs (2019). Working Environment Act. https://lovdata. no/dokument/NLE/lov/2005-06-17-62\#KAPITTEL_2. Accessed 8 Jan 2020.

Morano-Foadi, S. (2005). Scientific mobility, career progression, and excellence in the european research area. International Migration, 43(5), 133-162.

Morley, L., Alexiadou, N., Garaz, S., González-Monteagudo, J., \& Taba, M. (2018). Internationalisation and migrant academics: the hidden narratives of mobility. The International Journal of Higher Education Research, 76(3), 537-554.

Musselin, C. (2004). Towards a European Academic Labour Market?: some lessons drawn from empirical studies on academic mobility. Higher Education: The International Journal of Higher Education and Educational Planning, 48(1), 55-78. 
Negretti, R., \& Garcia-Yeste, M. (2015). "Lunch keeps people apart": the role of english for social interaction in a multilingual academic workplace. Multilingua. Journal Of Cross-Cultural And Interlanguage Communiciation, 34(1), 93-118.

NIFU, Nordic Institute for Studies in Innovation, Research and Education (2019). Doktorgrader. https:/www. nifu.no/fou-statistiske/fou-statistikk/doktorgrader/. Accessed 19 Sep 2018.

NIFU, Nordic Institute for Studies in Innovation, Research and education (2017). Mer mangfoldstatistikk. Arbeidsnotat 2017:4. https://nifu.brage.unit.no/nifu-xmlui/bitstream/handle/11250/2437152 /NIFUarbeidsnotat2017-4.pdf?sequence=5\&isAllowed=y. Accessed 10 Sept 2018.

OECD (2004). Internationalisation and Trade in Higher Education: Opportunities and Challenges. https://oi. org/10.1787/9789264015067-en

Otten, M. (2009). Academicus interculturalis? Negotiating interculturality in academic communities of practice. Intercultural Education, 20(5), 407-417.

Pherali, T. J. (2012). Academic mobility, language, and cultural capital: the experience of transnational academics in British higher education institutions. Journal of Studies in International Education, 16(4), 313-333.

Schwach, V., \& Elken, M. (2018) Å snakke fag på et språk andre forstår. Norsk fagspråk i høyere utdanning og arbeidsliv. NIFU Rapport 2018:20. Oslo: Nordisk institutt for studier av innovasjon, forskning og utdanning (NIFU).

Selmer, J., Lauring, J., \& Jonasson, C. (2013). Academic staff involvement and openness to diversity in international educational organisations: is there a moderating effect of shared language? Higher Education Quarterly, 67(2), 135-156.

Smyth, A., \& Holian, R. (2008). Credibility issues in research from within organisations. In P. Sikes \& A. Potts (Eds.), Researching education from the inside (pp. 33-47). United Kingdom: Routledge.

Stewart, A. (1998). The ethnographer's method. London: Sage.

Tange, H. (2010). Caught in the Tower of Babel: university lecturers' experiences with internationalisation. Language and Intercultural Communication, 10(2), 137-149.

Taylor, P., Hoyler, M., \& Evans, D. (2008). A geohistorical study of 'the rise of modern science': mapping scientific practice through urban networks, 1500-1900. Minerva, 46(4), 391-410.

Uusimaki, L., \& Garvis, S. (2017). Travelling academics: the lived experience of academics moving across countries. Higher Education Research and Development, 36(1), 187-200.

Walker, P. (2015). The globalisation of higher education and the sojourner academic: insights into challenges experienced by newly appointed international academic staff in a UK university. Journal of Research in International Education, 14(1), 61-74.

Publisher's note Springer Nature remains neutral with regard to jurisdictional claims in published maps and institutional affiliations. 